\title{
Classification of Muraenesocidae (Actinopterygii: Anguilliformes) in the East China Sea using Morphological and DNA Barcoding Approaches
}

\author{
Chaojie Yang ${ }^{1,2,3}$, Haishan Wang ${ }^{1,2,3}$, Le $\mathrm{Ye}^{1,2,3}$ and Zhi Chen ${ }^{1,2,3, *}$ \\ ${ }^{I}$ College of Fisheries and Life Science, Hainan Tropical Ocean University, Sanya \\ 572022, China \\ ${ }^{2}$ Key Laboratory of Utilization and Conservation for Tropical Marine Bioresources \\ (Hainan Tropical Ocean University), Ministry of Education, Sanya, 572022, China \\ ${ }^{3}$ Hainan Key Laboratory for Conservation and Utilization of Tropical Marine \\ Fishery Resources, Sanya, 572022, China
}

\begin{abstract}
A B S T RA C T
The identification of species constitutes the basic step in phylogenetic studies, biodiversity monitoring and conservation. The morphological descriptions and DNA barcoding study about Muraenesocidae in the East China Sea were old, rough and deficient. Morphometric measurements and meristic counts were taken for all collected Muraenesocidae samples in our present study. Teeth characters that are conclusive for the species were consistent with Muraenesox and were sufficient for separation from other Muraenesocidae species. The morphological results further suggested that only two Muraenesocidae species belonging to Muraenesox inhabit the East China Sea. This study confirms the occurrence of Muraenesox bagio (Hamilton, 1822) misreported as Congresox talabonoides (Bleeker, 1853) for the first time. Muraenesox bagio was diagnosed by: (1) head narrower, interorbital width (IOW) $<10 \% \mathrm{HL}$; (2) lateral-line pores before anus (PALL) 33 to 39; (3) dorsal-fin rays before anus (PADR) 49 to 57; (4) vertebrae 131 to 140 ; (5) red-brown to red color on the pectoral fin; when fresh the body is pale yellow with it being darker above and pale below; the very small black spots are little. In addition, the mitochondrial fragment of $12 \mathrm{~S}$ rRNA was also sequenced for the purpose of classification. Mean genetic distances within Muraenesox bagio (Hamilton, 1822) and Muraenesox cinereus (Forsskål, 1775) group were $1.77 \%$ and $0.41 \%$, respectively. Group mean distance between Congresox talabonoides (Bleeker, 1853 ) and other species ranged from $11.79 \%$ to $51.01 \%$. Species were also confirmed at genetic level. According to present study, Congresox talabonoides (Bleeker, 1853) might prefer warm water and live in lower latitude areas. Further sampling is indispensable in order to define their geographic limits.
\end{abstract}

Article Information
Received 11 November 2019
Revised 22 December 2019
Accepted 03 January 2020
Available online 12 February 2021
Authors' Contribution
ZC conceived and designed
experiments. CY, ZC, HW and LY
performed all experiments, analyzed
the data and wrote the manuscript.
ZC and CY arranged financial
support.
Key words
Muraenesocidae, The East China
Sea, Mis-identification, Marine eels,
Actinopterygii.

Received 11 November

Revised 22 December 2019

Accepted 03 January 2020

Authors' Contribution

the data and wrote the manuscript.

$\mathrm{ZC}$ and $\mathrm{CY}$ arranged financial

Actinopterygii.

\section{INTRODUCTION}

$\mathrm{T}$ here are probably 730 fish species in the East China Sea (Yamada et al., 2007; Zhao et al., 2012), constituting about $23 \%$ of all marine fish species of China (Chen and Zhang, 2016). They are systematically very diverse, ranging from ancient jawless species (Agnatha) to cartilaginous fishes (Chondrichthyes) and bony fish (Osteichthyes) (Zhu et al., 1963; Zhao et al., 2012). The identification of species constitutes the first basic step for biodiversity monitoring and conservation (Dayrat, 2005). Fish species identification mainly relies on morphometric and meristic characteristics (Strauss and Bond, 1990). However, there are pitfalls in relying primarily on morphology when attempting to identify fishes during

\footnotetext{
Corresponding author: change@139.com 0030-9923/2021/0002-0573 \$ 9.00/0

Copyright 2021 Zoological Society of Pakistan
}

various stages of their development not considered in original treatments or when examining fragmentary, partial or processed remains. Even when intact adult specimens are available, the morphological characteristics used to discern species can be so subtle that identification is difficult even for trained taxonomists (Ward et al., 2009).

It was proposed that the use of DNA barcoding methods can circumvent such a problem since 2003 (Hebert et al., 2003, 2004). The power of DNA barcoding to discriminate closely related species is largely attributable to the abundance of synonymous nucleotide changes (Ward et al., 2005; Ward and Holmes, 2007). Within species, the variation for a targeted DNA barcoding sequence is much lower compared with that between species or cryptic species. As a consequence, species are regularly delineated by a particular sequence or by a tight cluster of very similar sequences (Ward et al., 2009). The reconstruction of phylogenetic relationships based on molecular data in addition to the classical methodologies 
has helped to resolve taxonomic uncertainties for fishes (Hanel and Sturmbauer, 2000; Craig et al., 2001; Herran et al., 2001). In the past two decades, the rise in molecular biological techniques in marine forensic science has violently facilitated the development of accurate taxonomic identification of marine fish species distributed in the East China Sea (Lin et al., 2007; Gao et al., 2011; Chen et al., 2018; Zhang et al., 2019).

Muraenesocidae (pike congers), a widely-distributed family in the coastal waters of China and the Indo-western Pacific, has two recorded species in the East China Sea (Zhu et al., 1963; Zhao et al., 2012, 2016). These two species are Congresox talabonoides (Bleeker, 1853) and Muraenesox cinereus (Forsskål, 1775). Although many Chinese records about marine fishes have mentioned these two species, Muraenesocidae species taxonomy in the East China Sea is still unclear. To our knowledge, the morphological descriptions about local Muraenesocidae were too old, rough and deficient to identify and distinguish them from each other. For Muraenesox cinereus (Forsskål, 1775), the number range of vertebrae, dorsal fin rays before level of anus and lateral line pores before level of anus was too wide, which might include other species (Zhu et al., 1963; Zhao et al., 2012, 2016). The vomerine-teeth difference was the essential character to separate genus Congresox and genus Muraenesox. However, illustrations of Congresox talabonoides (Bleeker, 1853) showed a same tooth pattern with that of Muraenesox cinereus (Forsskål, 1775) (Zhu et al., 1963; Zhao et al., 2012, 2016). In some color illustrations, the only difference was that the pectoral-fin color was red brown in Congresox talabonoides (Bleeker, 1853) and cinereous in Muraenesox cinereus (Forsskål, 1775), respectively (Zhao et al., 2016). The pectoral-fin color was in somewhat conflict with other description of Congresox talabonoides (Bleeker, 1853) (Lin et al., 2013). Muraenesocidae species usually migrate annually, occurring off Jeju Island in winter, migrating to the coastal regions of the East China Sea or the Yellow Sea in spring, and returning to the Korea Strait off Japan or Korea again in the fall (NFRDI, 2013; Ji et al., 2015). As a consequence, the species records belonging to three countries should be the same. However, in Japanese systematics, Muraenesox bagio (Hamilton, 1822) have been found in abundance, but Congresox talabonoides (Bleeker, 1853) has never been recorded (Nakabo, 2002, 2013).

Based on above realities, we hypothesized that there were misidentifications of the greatly-recorded Muraenesocidae in the East China Sea. The first objective of the present study is to supply morphological descriptions and then investigate the record validities of Muraenesox cinereus (Forsskål, 1775) and Congresox talabonoides (Bleeker, 1853) based on our morphological evidence. The second objective is to classify all collected Muraenesocidae specimens using DNA barcoding. Our investigation ultimately intended to provide an update on Muraenesocidae composition in the East China Sea.

\section{MATERIALS AND METHODS}

\section{Sampling}

Samples were collected from Zhoushan, Wenzhou and Fuzhou, from August 2019 to November 2019. All specimens reported here were collected by commercial fishing trawlers and bottom long-line in the East China Sea at depths of $20 \sim 100 \mathrm{~m}$. For each station, there are hundreds of specimens suffering a brief on-site examination. Then, the fresh, representative and intact adult specimens covering all recorded types in the past Chinese literatures were collected (Fig. 1).

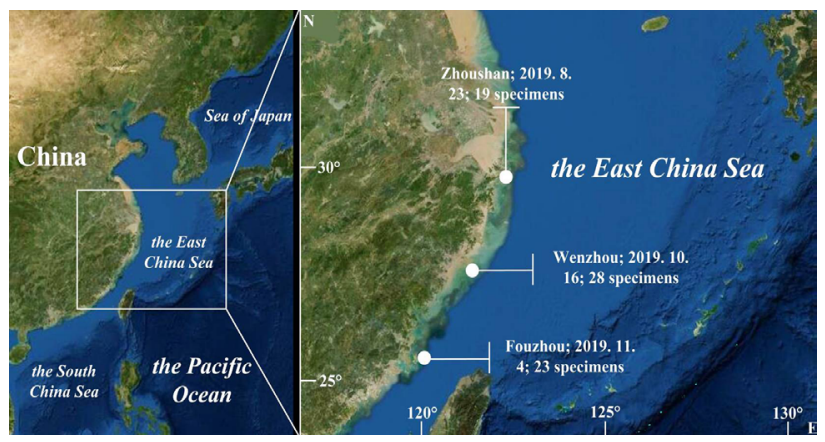

Fig. 1. Sampling location, date, and number of specimens in this study.

All specimens were frozen and immediately transported to laboratory. Identification was carried out based on morphological characteristics (Smith, 1999; Nakabo, 2002; Lin et al., 2013). The brief information of classification was shown in Table I. A piece of muscle tissue was obtained from each specimen and preserved in $95 \%$ ethanol. All examined specimens were frozen again and preserved at $-20^{\circ} \mathrm{C}$.

\section{Morphological study}

Measurements were conducted as a straight line (point to point), and dial calipers were used to record to the nearest $0.1 \mathrm{~mm}$. The morphological measurements and meristic counts were utilized as presented by Böhlke (1989) and Lin et al. (2013). The following measurement abbreviations are used: TL (total length), PAL (pre-anal length), TR (trunk length), PDL (pre-dorsal length), HL (head length), DGO (body depth at gill opening), GO (gill opening depth), IOW (interorbital width), UJ (length of upper jaw), LJ (length of lower jaw), E (diameter of eye), 
Table I.- Information of the Muraenesocidae samples in this study.

\begin{tabular}{|c|c|c|c|c|c|}
\hline \multirow{3}{*}{$\begin{array}{l}\text { Sampling } \\
\text { stations }\end{array}$} & \multicolumn{5}{|c|}{ Number of specimens } \\
\hline & \multirow[t]{2}{*}{ Total number } & \multicolumn{2}{|c|}{$\begin{array}{l}\text { According to the descriptions in } \\
\text { Chinese }\end{array}$} & \multicolumn{2}{|c|}{$\begin{array}{l}\text { According to the descriptions in other languages } \\
\text { (English, Japanese, } \text { etc.) }\end{array}$} \\
\hline & & Muraenesox & Congresox & Muraenesox & Congresox \\
\hline Zhoushan & 19 & 13 & 6 & 19 & 0 \\
\hline Wenzhou & 28 & 20 & 8 & 28 & 0 \\
\hline Fuzhou & 23 & 19 & 4 & 23 & 0 \\
\hline
\end{tabular}

S (snout length), P (pectoral fin length), VG (ventral width between gill openings), PDLL (lateral-line pores before dorsal fin origin), PALL (lateral-line pores before anus), PADR (pre-anal dorsal fin rays), PR (pectoral fin rays), TV (total vertebrae), PAV (pre-anal vertebrae), PDV (pre-dorsal vertebrae), PCV (pre-caudal vertebrae), MVF (mean vertebrae formula). Drawings and photographs were made in this study as well.

\section{Molecular analyses}

Genomic DNA was isolated from muscle tissue by proteinase $\mathrm{K}$ digestion followed by a standard phenolchloroform method. The fragment of mitochondrial DNA 12S rRNA was amplified using the primers MiFish-U-F: 5'-GTCGGTAAAACTCGTGCCAGC-3'; and MiFishU-R: 5'-CATAGTGGGGTATCTAATCCCAGTTTG-3' (Miya et al., 2015). Each polymerase chain reaction (PCR) was performed in a $25 \mu \mathrm{L}$ reaction mixture containing 17.5 $\mu \mathrm{L}$ of ultrapure water, $2.5 \mu \mathrm{L}$ of $10 \times$ PCR buffer, $2 \mu \mathrm{L}$ of dNTPs, $1 \mu \mathrm{L}$ of each primer $(5 \mu \mathrm{mol} / \mathrm{L}), 0.15 \mu \mathrm{L}$ of Taq polymerase, and $1 \mu \mathrm{L}$ of DNA template. PCR amplification was performed in a Biometra thermal cycler under the following conditions: $5 \mathrm{~min}$ of initial denaturation at $95^{\circ} \mathrm{C} ; 35$ cycles of $25 \mathrm{~s}$ at $94^{\circ} \mathrm{C}$ for denaturation, $25 \mathrm{~s}$ at $52^{\circ} \mathrm{C}$ for annealing, and $25 \mathrm{~s}$ at $72^{\circ} \mathrm{C}$ for extension; and a final extension at $72^{\circ} \mathrm{C}$ for $5 \mathrm{~min}$. The PCR products were purified with a Gel Extraction Mini Kit. The purified product was used as the template DNA for cycle sequencing reactions performed using the BigDye Terminator Cycle Sequencing Kit, and bi-directional sequencing was conducted on an ABI Prism 3730 automatic sequencer (Applied Biosystems, Foster City, CA, USA) with the same primers used for PCR amplification.

To determine the phylogenetic relationships of specimens, 12S rRNA sequences of Muraenesocidae species recorded in China were downloaded from GenBank for comparative analysis (Table II). Sequence of Anguilla japonica (Temminck and Schlegel, 1846) was used to root the tree. After aligning by DNASTAR software (Madison, WI, USA), a neighbor-joining (NJ) tree was created. The distances between and within groups were calculated using MEGA 5.0 (Tamura et al., 2011) with 1,000 bootstrapping replications based on evolutionary distances calculated using the best selected K2P model.

Table II.- Related 12S rRNA sequences downloaded from NCBI for phylogenetic tree study.

\begin{tabular}{lc}
\hline Species & GenBank accession No. \\
\hline $\begin{array}{l}\text { Congresox talabonoides } \\
\text { (Bleeker, 1853) }\end{array}$ & DQ645658 \\
$\begin{array}{l}\text { Muraenesox bagio } \\
\text { (Hamilton, 1822) }\end{array}$ & AB049988, LC277765, \\
$\begin{array}{l}\text { Muraenesox cinereus } \\
\text { (Forsskål, 1775) }\end{array}$ & AP010852 \\
$\begin{array}{l}\text { Oxyconger leptognathus } \\
\text { (Bleeker, 1858) }\end{array}$ & LC020903, AF417318 \\
$\begin{array}{l}\text { Gavialiceps taeniola } \\
\text { (Alcock, 1889) }\end{array}$ & AF417319, LC327227 \\
$\begin{array}{l}\text { Anguilla japonica } \\
\text { (Temminck and Schlegel, 1846) }\end{array}$ & AF417320 \\
\hline
\end{tabular}

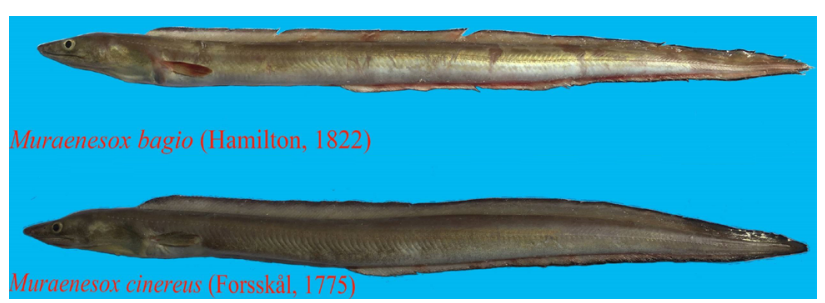

Fig. 2. Lateral views of whole body.

\section{RESULTS}

\section{Morphological characters}

According to their morphological characteristics, only one genus contains 2 species in the East China Sea. The generally morphological features and teeth pattern of them are shown in Figures 2 and 3. Above all, their teeth numbers are abundant, conical-granular and hidden when mouth is closed. Maxillary teeth with several rows extend inward on the eye level. Vomer teeth plate is elongated with three rows; the middle row is enlarged, blade-like, sharp teeth which has a wider base (Figure 3A). Besides, specimens in this study have the following characteristics: 
body is moderately elongate, and it is cylindrical anteriorly but becomes compressed posteriorly, with a tapering and flexible tail. Head is acute and elongate. It has an elongate and pointed snout which is slightly narrow and contains a fleshy tip; the upper jaw is curved, and projects beyond the lower jaw with the premaxilla level. The anterior nostril is tubular, laterally and located in the middle between the upper jaw tip and posterior nostril. The posterior nostril is elliptical and located two thirds in front of the eye at the mid-eye level. Rictus extends obviously beyond the posterior margin of the eye. The eye is ellipse and well developed. Gill opening is slit-like, large, located on the lower side, somewhat ventrally, nearly meeting on the end of ventral side, and its height almost reaches half of the body depth. Lateral-line is complete and scale is absent.
The dorsal fin originates slightly before the gill opening, it is well developed and confluent with caudal fin and anal fin; Pectoral fins are well developed. Anus is located before mid-body, about two fifth of the body.

Although all specimens have above similar characters, the two Muraenesox species could also be easily separated by the following feature (Figure 3; Table III):

Muraenesox bagio: (1) head narrower, interorbital width (IOW) $<10 \% \mathrm{HL}$; (2) lateral-line pores before anus (PALL) 33 to 39; (3) dorsal-fin rays before anus (PADR) 49 to 57 ; (4) vertebrae 131 to 140 ; (5) red-brown to red color on the pectoral fin (Fig. 3B, the upper one); when fresh the body is pale yellow with it being darker above and pale below (Fig. 2); the very small black spots are little (Fig. 3C).

Table III.- Comparative counts of Muraenesox bagio (Hamilton, 1822) and Muraenesox cinereus (Forsskål, 1775) from different records.

\begin{tabular}{|c|c|c|c|c|c|}
\hline & & \multicolumn{2}{|c|}{ Records in this study } & \multicolumn{2}{|c|}{ Records in references } \\
\hline & & Specimens & Specimens & Lin et al. (2013) & Lin et al.(2013) \\
\hline & & $\begin{array}{c}\text { Muraenesox bagio } \\
\text { (Hamilton, 1822) } \\
(\mathrm{n}=15)\end{array}$ & $\begin{array}{c}\text { Muraenesox cinereus } \\
\text { (Forsskål, 1775) } \\
(\mathrm{n}=\mathbf{5 5})\end{array}$ & $\begin{array}{c}\text { Muraenesox bagio } \\
\text { (Hamilton, 1822) } \\
(n=7)\end{array}$ & $\begin{array}{c}\text { Muraenesox cinereus } \\
\text { (Forsskål, 1775) } \\
(\mathrm{n}=76)\end{array}$ \\
\hline & $\mathrm{SL}(\mathrm{mm})$ & $434 \sim 812$ & $380 \sim 836$ & $383 \sim 855$ & $165 \sim 1005$ \\
\hline \multirow[t]{9}{*}{ Counts } & PDV & $7 \sim 10(8.87 \pm 0.44)$ & $7 \sim 11(8.15 \pm 0.58)$ & $8 \sim 9$ & $7 \sim 10$ \\
\hline & PAV & $33 \sim 39(37.32 \pm 1.01)$ & $41 \sim 48(45.11 \pm 1.49)$ & $37 \sim 38$ & $43 \sim 48$ \\
\hline & TV & $131 \sim 140(137.06 \pm 2.28)$ & $147 \sim 156(150.94 \pm 2.17)$ & $137 \sim 138$ & $149 \sim 155$ \\
\hline & PCV & $54 \sim 60(56.87 \pm 1.43)$ & $61 \sim 67(64.45 \pm 1.61)$ & $56 \sim 58$ & $64 \sim 66$ \\
\hline & MVF & $9-37-137$ & 8-45-151 & $9-38-138$ & $8-45-151$ \\
\hline & PDLL & $5 \sim 8(6.67 \pm 0.94)$ & $4 \sim 10(6.51 \pm 1.22)$ & $6 \sim 7$ & $4 \sim 8$ \\
\hline & PALL & $33 \sim 39(36.16 \pm 1.34)$ & $41 \sim 47(43.34 \pm 1.24)$ & $35 \sim 37$ & $40 \sim 46$ \\
\hline & PADR & $49 \sim 57(52.82 \pm 2.11)$ & $66 \sim 78(72.51 \pm 2.28)$ & $50 \sim 54$ & $66 \sim 80$ \\
\hline & PR & $16 \sim 17(16.94 \pm 0.17)$ & $16 \sim 18(16.96 \pm 0.41)$ & 17 & $15 \sim 18$ \\
\hline \multirow[t]{6}{*}{ As \% TL } & PAL & $36.25 \sim 41.71(38.56 \pm 2.28)$ & $36.16 \sim 49.40(40.29 \pm 2.75)$ & $36.55 \sim 42.78$ & $36.21 \sim 46.92$ \\
\hline & Tail & $53.66 \sim 62.58(56.83 \pm 2.97)$ & $54.12 \sim 63.02(55.45 \pm 2.38)$ & $57.22 \sim 63.45$ & $55.68 \sim 63.92$ \\
\hline & TR & $23.34 \sim 25.81(24.20 \pm 1.09)$ & $17.66 \sim 27.25(23.48 \pm 2.14)$ & $22.99 \sim 23.94$ & $19.22 \sim 29.27$ \\
\hline & PDL & $13.20 \sim 14.75(14.03 \pm 0.65)$ & $12.20 \sim 14.34(13.69 \pm 0.50)$ & $14.06 \sim 14.36$ & $12.01 \sim 15.28$ \\
\hline & HL & $13.94 \sim 16.36(14.91 \pm 1.10)$ & $12.52 \sim 16.93(14.32 \pm 1.46)$ & $14.06 \sim 14.62$ & $12.84 \sim 16.53$ \\
\hline & DGO & $4.49 \sim 6.45(6.05 \pm 0.94)$ & $4.26 \sim 6.74(6.06 \pm 0.81)$ & $4.62 \sim 5.06$ & $3.96 \sim 7.28$ \\
\hline As $\%$ DOG & GO & $34.38 \sim 55.88(44.74 \pm 8.76)$ & $21.21 \sim 44.44(33.58 \pm 5.11)$ & - & - \\
\hline \multirow[t]{7}{*}{ As $\% \mathrm{HL}$} & IOW & $8.63 \sim 9.74(8.97 \pm 0.39)$ & $11.75 \sim 17.39(13.26 \pm 1.18)$ & $9.23 \sim 10$ & $11.39 \sim 20.37$ \\
\hline & UJ & $46.90 \sim 51.00(48.94 \pm 1.81)$ & $45.25 \sim 52.33(48.51 \pm 1.99)$ & $48.87 \sim 49.99$ & $46.04 \sim 55.41$ \\
\hline & LJ & $39.02 \sim 45.33(41.43 \pm 2.91)$ & $38.02 \sim 54.00(42.96 \pm 3.81)$ & $44 \sim 45.94$ & $39.73 \sim 52.43$ \\
\hline & $\mathrm{E}$ & $9.68 \sim 13.00(11.28 \pm 1.17)$ & $9.46 \sim 15.43(11.82 \pm 1.48)$ & $11.33 \sim 13.21$ & $9.99 \sim 15.54$ \\
\hline & $\mathrm{S}$ & $25.81 \sim 32.33(21.18 \pm 1.91)$ & $24.68 \sim 33.99(28.21 \pm 2.10)$ & $26.07 \sim 29.23$ & $26.96 \sim 32.83$ \\
\hline & $\mathrm{P}$ & $30.44 \sim 43.55(38.11 \pm 2.84)$ & $31.00 \sim 43.66(40.01 \pm 3.02)$ & $29.82 \sim 35.73$ & $30.13 \sim 44.03$ \\
\hline & VG & $6.67 \sim 9.68(8.33 \pm 1.24)$ & $5.26 \sim 9.33(6.87 \pm 1.13)$ & - & - \\
\hline
\end{tabular}


Table IV.- Genetic distances within (on the diagonal, bold font) and between (below the diagonal, normal font) species.

\begin{tabular}{lcccccc}
\hline & $\begin{array}{c}\text { Muraenesox } \\
\text { bagio }\end{array}$ & $\begin{array}{c}\text { Muraenesox } \\
\text { cinereus }\end{array}$ & $\begin{array}{c}\text { Congresox } \\
\text { talabonoides }\end{array}$ & $\begin{array}{c}\text { Oxyconger } \\
\text { leptognathus }\end{array}$ & $\begin{array}{c}\text { Anguilla } \\
\text { japonica }\end{array}$ & $\begin{array}{c}\text { Gavialiceps } \\
\text { taeniola }\end{array}$ \\
\hline Muraenesox bagio & $\mathbf{0 . 0 1 7 7}$ & & & & & \\
Muraenesox cinereus & 0.0426 & $\mathbf{0 . 0 0 4 1}$ & & & & \\
Congresox talabonoides & 0.1339 & 0.1179 & - & & \\
Oxyconger leptognathus & 0.1589 & 0.1894 & 0.2725 & $\mathbf{0 . 0 0 0 0}$ & & - \\
Anguilla japonica & 0.1950 & 0.2000 & 0.2420 & 0.2365 & 0.2259 & - \\
Gavialiceps taeniola & 0.3504 & 0.3539 & 0.5101 & 0.3272 & & \\
\hline
\end{tabular}

Muraenesox cinereus: (1) head broader, interorbital width $(\mathrm{IOW})>10 \% \mathrm{HL}$; (2) lateral-line pores before anus (PALL) 41 to 47 ; (3) dorsal-fin rays before anus (PADR) 66 to 78 ; (4) vertebrae 147 to 156 ; (5) cinerous to black color on the pectoral fins (Fig. 3B, the lower one); when fresh it is light gray to gray, with a deep color above (Fig. 2); the very small black spots are numerous (Fig. 3D).

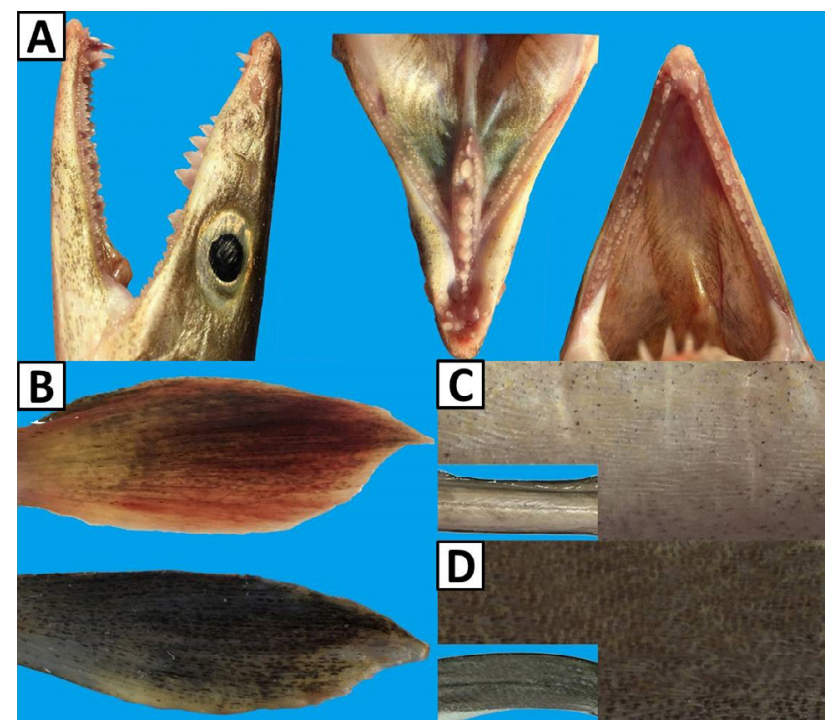

Fig. 3. Some characteristic difference between Muraenesox bagio and Muraenesox cinereus in the East China Sea.

\section{Molecular analyses}

For each species, two specimens of each population randomly chosen were sequenced. Twelve 172-bp-long sequences of $12 \mathrm{~S}$ rRNA gene fragments were obtained. After combined the downloaded sequences of Muraenesocidae, a total of 22 sequences were used for analysis. A neighborjoining phylogenetic tree was constructed using MEGA 5.0 (Fig. 4). The 12S rRNA sequences of specimens from the East China Sea clustered in three groups, and 3 haplotypes were defined. All haplotype sequences were submitted to GenBank with the following accession numbers: MN811203-MN811205. The haplotype 1 (Hap4) was shared by 6 specimen of Muraenesox cinereus (Forsskål, 1775). The haplotype 3 (Hap-3) were shared by 1 specimens of Muraenesox bagio (Hamilton, 1822) from Zhoushan. The remaining specimens of Muraenesox bagio (Hamilton, 1822) shared the haplotype 2 (Hap-2). Table IV shows the genetic distances among all species. The mean distance among all species was $14.98 \%$. Within mean group distance of Muraenesox bagio (Hamilton, 1822) and Muraenesox cinereus (Forsskål, 1775) were 1.77\% and $0.41 \%$, respectively. Genetic distance between our 12 Muraenesox specimens and Congresox talabonoides (Bleeker, 1853) downloaded from NCBI was $>11.79 \%$, which indicated that our specimen couldn't be Congresox talabonoides at all.

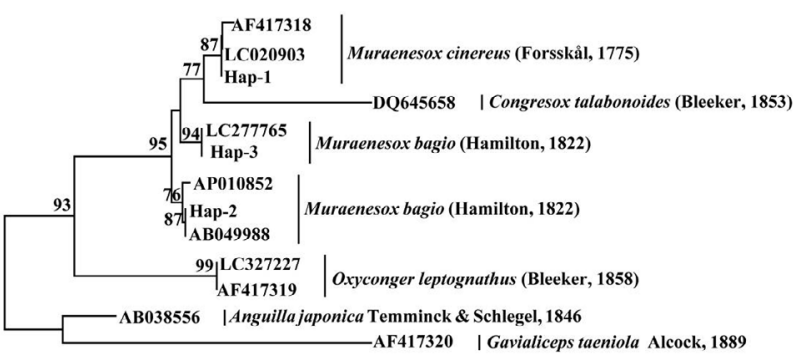

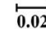

Fig. 4. Phylogenetic tree based on neighbor-joining analysis of $12 \mathrm{~S}$ rRNA sequence. Numbers above branches indicate neighbor-joining bootstrap percentages. Only bootstrap values of $>60 \%$ are shown in the above $\mathrm{NJ}$ tree.

\section{DISCUSSION}

The morphological characters of specimens used in this study were photographed, counted and compared with previously representative records on Figures 2, 3 and Table III. The specimens in the East China Sea were characterized by: blade-like rather than needle-like teeth 
on the vomer. This decisive phenotypic trait was consistent with the typical Muraenesox specimens, and ruled out the possibility of genus Congresox these samples belonging to Smith (1999) and Nakabo (2013). According to our present study, it was concluded that previous records of Congresox talabonoides (Bleeker, 1853) were the mis-identification of Muraenesox bagio (Hamilton, 1822) in reality, and the latter was a new record in the East China Sea (Zhu et al., 1963; Zhao et al., 2012, 2016).

Congresox talabonoides (Bleeker, 1853) was initially recorded as Muraenesox talabonoides (Bleeker, 1853) (Smith, 1999; Lin et al., 2013; Zhao et al., 2016), both genus being characterized by: body long, compressed along tail; snout very pointed, mouth terminal, large, extending well beyond eye; teeth always large, prominent, especially in front sharp, multi-serial on jaws and typically in 3 rows on vomer; gill opening a vertical or oblique slit in front of pectoral fin; no spines in fins; dorsal fin begins before gill opening; pectoral fins always present; no pelvic fins; no scales. By reviewing all morphological characteristics including our present results, it could be obviously found that Muraenesox and Congresox were very similar. Almost all morphological characteristics were much overlapped (Smith, 1999; Lin et al., 2013; Nakabo, 2013). These might be the reason why Muraenesox bagio (Hamilton, 1822) from the East China Sea was misidentified as Congresox talabonoides (Bleeker, 1853) by native ichthyologists.

DNA barcoding was recognized as an effective and reliable method for species identification (Hebert et al., 2003; Domingues et al., 2013). The impossibility that specimens belonged to Congresox talabonoides (Bleeker, 1853) was also demonstrated from genetically phylogenetic relationship. We identified that the sequence of Congresox talabonoides (Bleeker, 1853) from NCBI (DQ645658) was distinguished from other species by distance $=0.1179 \sim 0.5101$. Within mean group distance of Muraenesox bagio (Hamilton, 1822) and Muraenesox cinereus (Forsskål, 1775) were $1.77 \%$ and $0.41 \%$, respectively. The interspecific distance was respectively about 7.56 and 28.76 times larger than intraspecific distance. Together, both the morphological and genetic analysis strongly supported the validity of Muraenesox bagio (Hamilton, 1822) and nonexistence of Congresox talabonoides (Bleeker, 1853) in the East China Sea.

It was reported that Congresox talabonoides (Bleeker, 1853) was widely distributed in the coastal waters of China (Zhu et al., 1963; Jin, 2006; Tang, 2006; Zhao et al., 2012, 2016). We have also tried our best to collect more specimens from China seas. But it seemed that fishermen could only see the occurrence of Congresox talabonoides (Bleeker, 1853) in the East China Sea. This species might prefer warm water and live in lower latitude areas.
Further domestic and overseas specimen collection is also indispensable in order to define its clearly geographic limits.

Accurate identification of fish is essential and would assist in managing fisheries for long-term sustainability, and improve ecosystem research and conservation. This nature will require careful morphological analysis from expert taxonomists before any final recommendations can be made (Ward et al., 2005; Hajibabaei et al., 2007; Gross, 2012). Mitochondrial sequence divergences are strongly linked to the process of speciation, and DNA barcoding and morphological analysis should go hand-in-hand. We hope this study will not only promote the sustainable exploitation, biodiversity conservation and fisheries management of Muraeneso distributed in the East China Sea but also contribute to species identification within this family.

\section{ACKNOWLEDGEMENTS}

This work was supported by the Scientific Research Foundation of Hainan Tropical Ocean University (No. RHDRC201907), the start-up foundation for Doctor of Hainan Tropical Ocean University (RHDXB201809) and the School-Level Youth Special Foundation of Hainan Tropical Ocean University (RHDQN201826).

\section{Statement of conflict of interest}

There are no conflicts of interest and authors are solely responsible for the contents and writing of the paper.

\section{REFERENCES}

Böhlke, E.B. (ed.), 1989. Methods and terminology. In: Fishes of the Western North Atlantic. Sears Foundation for Marine Research, Yale University, New Haven, America, pp. 1-7.

Chen, D.G. and Zhang, M.Z., 2016. Marine fishes of China. China Ocean University Press, Qingdao, China, pp. 1-3.

Chen, Z., Wang, X.Y., Zhang, J., Li, Y., Gao, T.X. and Lin, L.S., 2018. First record of the Chinese fanray, Platyrhina sinensis (Elasmobranchii: Myliobatiformes: Platyrhinidae), in the seawaters of Zhujiajian, Zhoushan, China. Acta Ichthyol. Piscat., 48: 409-414. https://doi.org/10.3750/ AIEP/02435

Craig, M.T., Pondella, D.J., Franck, J.P. and Hafner, J.C., 2001. On the status of the serranid fish genus Epinephelus: Evidence for paraphyly based upon 16s rDNA sequence. Mol. Phylogenet. Evolut., 19: 121-130. https://doi.org/10.1006/mpev.2000.0913 
Dayrat, B., 2005. Towards integrative taxonomy. Biol. J. Linn. Soc., 85: 407-415. https://doi.org/10.1111/ j.1095-8312.2005.00503.x

Domingues, R.R., Amorim, A.F. and Hilsdorf, A.W.S., 2013. Genetic identification of Carcharhinus sharks from the southwest Atlantic Ocean (Chondrichthyes: Carcharhiniformes). J. appl. Ichthyol., 29: 738-742. https://doi.org/10.1111/ jai. 12154

Gao, T.X., Ji, D.P., Xiao, Y.S., Xue, T.Q., Yanagimoto, T. and Setoguma, T., 2011. Description and DNA barcoding of a new Sillago species, Sillago sinica (Perciformes: Sillaginidae), from coastal waters of China. Zool. Stud., 50: 254-263.

Gross, M., 2012. Barcoding biodiversity. Curr. Biol., 22: 73-76. https://doi.org/10.1016/j.cub.2012.01.036

Hajibabaei, M., Singer, G.A.C., Hebert, P.D.N. and Hickey, D.A., 2007. DNA barcoding: How it complements taxonomy, molecular phylogenetics and population genetics? Trends Genet., 23: $167-$ 172. https://doi.org/10.1016/j.tig.2007.02.001

Hanel, R. and Sturmbauer, C., 2000. Multiple recurrent evolution of trophic types in northeastern Atlantic and Mediterranean seabreams (Sparidae, Percoidei). J. mol. Evolut., 50: 276-283. https://doi. org/10.1007/s002399910032

Hebert, P.D.N., Cywinska, A., Ball, S.L. and Waard, J.R., 2003. Biological identification through DNA barcodes. Proc. R. Soc. B: Biol. Sci., 270: 313-321. https://doi.org/10.1098/rspb.2002.2218

Herbert, P.D.N., Stoeckle, M.Y., Zemlak, T.S. and Francis, C.M., 2004. Identification of birds through DNA barcodes. PLoS Biol., 2: 1657-1663. https:// doi.org/10.1371/journal.pbio.0020312

Herran, R., Rejon, C.R., Rejon, M.R. and GarridoRamos, M.A., 2001. The molecular phylogeny of the Sparidae (Pisces, Perciformes) based on two satellite DNA families. Heredity, 87: 691-697. https://doi.org/10.1046/j.1365-2540.2001.00967.x

Ji, H.S., Kim, J.K., Oh, T.Y., Choi, K.H., Choi, J.H., Seo, Y.I. and Lee, D.W., 2015. Larval distribution pattern of Muraenesox cinereus (Anguilliformes: Muraenesocidae) leptocephali in waters adjacent to Korea. Ocean Sci. J., 50: 537-545. https://doi. org/10.1007/s12601-015-0049-6

Jin, X.B., 2006. Fauna sinica of China. Science Press, Beijing, China, pp. 172-207.

Lin, J., Shao, K.T. andChen,H.M.,2013. Taxonomicstudy of pike congers (Anguilliformes: Muraenesocidae) with identification of Muraenesocid collections in Taiwan. J. Mar. Sci. Technol., 21(Suppl): 166-174.

Lin, L.S., Cheng, J.H. and Gao, T.X., 2007. A new recorded species of Paratrachichthys from central East China Sea. Mar. Fish. Res., 28: 80-82.

Miya, M., Sato, Y., Fukunaga, T., Sado, T., Poulsen, Y., Sato, K., Minamoto, T., Yamamoto, S., Yamanaka, H., Araki, H., Kondoh, M. and Iwasaki, W., 2015. MiFish, a set of universal PCR primers for metabarcoding environmental DNA from fishes: Detection of $>230$ subtropical marine species. $R$. Soc. Open Sci., 2: 150088. https://doi.org/10.1098/ rsos. 150088

Nakabo, T., 2002. Fishes of Japan with pictorial keys to the species, English edition. Tokai University Press, Kanagawa, Japan, pp. 280.

Nakabo, T., 2013. Fishes of Japan with pictorial keys to the species, Third edition. Tokai University Press, Kanagawa, Japan, pp. 288.

NFRDI, 2013. Ecology and fishing ground of major commercial species in the Korean waters. National Fisheries Research and Development Institute, YeMoon-Publishing, Busan, Korea, pp. 147-168.

Smith, D.G., 1999. Anguilliformes. In: FAO species identification guide for fishery purposes (eds. K.E. Carpenter and V.H. Niem). The Living Marine Resources of the Western Central Pacific, Volume 4, Bony Fishes Part 2 (Mugilidae to Carangidae). FAO, Rome, pp. 1651-1718.

Strauss, R. and Bond, C., 1990. Taxonomic methods: Morphology. In: Methods for fish biology (eds. C.B. Schreck and P.B. Moyle). American Fisheries Society, New York, pp. 109-140.

Tamura, K., Peterson, D., Peterson, N., Stecher, G., Nei, M. and Kumar, S., 2011. MEGA5: Molecular evolutionary genetics analysis using maximum likelihood, evolutionary distance, and maximum parsimony methods. Mol. Biol. Evolut., 28: 27312739. https://doi.org/10.1093/molbev/msr121

Tang, Q., 2006. Marine fishery resources and habitat of China's exclusive economic zone. Science Press, Beijing, pp. 370.

Ward, R.D., Hanner, R. and Hebert, P.D.N., 2009. The campaign to DNA barcode all fishes, FISH-BOL. J. Fish Biol., 74: 329-356. https://doi.org/10.1111/ j.1095-8649.2008.02080.x

Ward, R.D. and Holmes, B.H., 2007. An analysis of nucleotide and amino acid variability in the barcode region of cytochrome c oxidase i ( cox1) in fishes. Mol. Ecol. Notes, 7: 899-907. https://doi. org/10.1111/j.1471-8286.2007.01886.x

Ward, R.D., Zemlak, T.S., Innes, B.H., Last, P.R. and Herbert, P.D.N., 2005. DNA barcoding Australia's fish species. Phil. Trans. R. Soc. London Ser. B: Biol. Sci., 360: 1847-1857. https://doi.org/10.1098/ 
rstb. 2005.1716

Yamada, U., Tokimura, M., Horikawa, H. and Nakabo, T., 2007. Fishes and fisheries of the East China and Yellow Seas. Tokai University Press, Kanagawa, Japan, pp. 1-10.

Zhang, L.Y., Zhou, Z.D., Li, H.P., Qiao, Y.L. and Zhang, Y.P., 2019. The mitochondrial COI gene reveals the genetic diversity of chub mackerel (Scomber japonicus) in the Taiwan Strait and its adjacent waters. Pakistan J. Zool., 51: 935-943. http://dx.doi. org/10.17582/journal.pjz/2019.51.3.935.943
Zhao, S.L., Chen, J. and Yu, F.J., 2012. Study on species composition, distribution and resources of Zhejiang marine fishes. J. Zhejiang Ocean Univ. (Nat. Sci.), 31: 1-11.

Zhao, S.L., Xu, H.X., Zhong, J.S. and Chen, J., 2016. Marine fish of Zhejiang province. Zhejiang Science and Technology Press, Hangzhou, China, pp. 1-5.

Zhu, Y.D., Zhang, C.L. and Cheng, Q.T., 1963. Fishes of East China Sea. Science Press, Beijing, China, pp. 1-4. 